\title{
INVEST
}

INVEST Working Papers 28/2021

\section{Lone mothers and child support receipt in 21 European countries}

Mia Hakovirta

Merita Jokela

26.4.2021 
The Inequalities, Interventions, and New Welfare State (INVEST) aims at increasing wellbeing of Finnish society during childhood, youth and early adulthood and preventing psychosocial risks compromising such development through innovative interventions. Based on cutting-edge research on the conditions and mechanisms involved at different periods of development, INVEST will evaluate and develop various universal and targeted interventions to improve the efficiency of the current welfare state institutions at critical points of the early life course. INVEST aims at providing a new model for the welfare states that is more equal, better targeted to problem groups, more anticipatory as well as economically and socially sustainable. INVEST is a Flagship project of the Academy of Finland. 


\title{
Title page
}

Lone mothers and child support receipt in 21 European countries

\author{
Dr. Mia Hakovirta \\ Department of Social Research, \\ 20014 University of Turku, Finland \\ miahak@utu.fi
}

Dr. Merita Jokela

Institution of Health and Welfare,

Helsinki, Finland

merita.jokela@thl.fi 
Lone mothers and child support receipt in 21 European countries 


\begin{abstract}
With increasing trends in divorce, separation, and multi-partner fertility, more families have become subject to child support policies. This paper explores child support receipt in 21 European countries using 2017-2018 European Union Statistics on Income and Living Conditions data. We investigated: 1) cross-country differences in the prevalence and amount of child support received, and 2) the determinants of child support receipt among lone mothers across countries. We found that the proportion of lone-mother families receiving child support ranged from 16 percent in Luxembourg to 75 percent in the Czech Republic, with large variations in the amount of child support received. Our results suggested that the socioeconomic characteristics of lone mothers, including marital status, education, employment status, and income, were associated with the likelihood of receiving child support in most countries but these associations varied significantly across countries.
\end{abstract}




\section{Introduction}

The proportion of all families with children headed by a lone mother has increased in European Union (EU) countries in recent decades (Bernandi, 2018; Bradshaw, Keung and Chzhen, 2018; Nieuwenhuis, 2020). Lone mothers are commonly perceived as being among the most vulnerable groups in many societies, facing inadequate resources, employment, and policies (Nieuwenhuis and Maldonado, 2018). Lone mothers often have physical custody of children, making it difficult to increase their workload to compensate for former partners' income; thus, many lone mothers live in poverty (Mortelmans, 2020). One factor that may increase the economic well-being of lone mothers in post-separation is child support, where one parent is obligated to pay cash to the other parent to share the costs of raising their children (International Network of Child Support Scholars, 2021).

Child support is associated with many positive outcomes. It reduces poverty if received and has the potential to reduce economic vulnerability among lone mothers and their children (author Hakovirta, 2011; Meyer and Hu, 1999; Skinner, Cook and Sinclair, 2017; Cuesta, Hakovirta and Jokela, 2018). It improves various outcomes among children, including educational attainment and cognitive development (Nepomnyaschy, Magnuson and Berger 2012) and children's health (Baughman, 2013). It protects children from food insecurity in middle childhood (Nepomnyaschy et al, 2014) and child support payments reduce the risk of child welfare involvement (Cancian, Yang and Shook Slack, 2013). Despite these positive outcomes, changes in social and economic factors have contributed to poorer child support outcomes over time (Case, Lin and McLanahan 2003; Huang 2009). Furthermore, a significant proportion of lone-parent families with children eligible for child support do not receive it (Cuesta and Meyer, 2012; Rios-Salas and Meyer 2014; 
Cuesta et al., 2018; Hakovirta and Jokela, 2019). Lack of financial support from non-resident fathers places a financial burden on lone mothers, which has led to a growing interest in the determinants of child support receipt.

Little empirical research exists on compliance and the determinants of child support receipt, especially from a comparative perspective. Thus, there is limited knowledge concerning how many eligible children receive child support across Europe and whether and how different cultural and policy contexts influence child support receipt among lone-mother families. This article addresses this research gap through examining the receipt of child support and the characteristics associated with child support receipt among lone mothers in 21 European countries using 2017-2018 European Union Statistics on Income and Living Conditions (EUSILC) data. We focused on lone mothers as these types of families comprise the majority, with the proportion of single fathers receiving child support being minimal (Vnuk, 2019; Nieuwenhuis, 2020). This study aimed to examine: (1) the extent to which the levels of child support receipt and amounts received differed between European countries, and 2) what were the individual-level determinants of child support receipt and whether these child support correlates differed between countries. We focussed only on private contributions and child support received from non-resident fathers, as not all countries operate guaranteed child support schemes where the state provides some financial support if a non-resident parent is not paying (Skinner, Bradshaw and Davidson, 2007).

This study contributes to the literature in several ways. First, previous comparative studies show substantial cross-country differences in the receipt rates and amounts of child support, but the factors associated with child support receipt in Europe have not been rigorously studied (see 
countries included in this study in Table 1). This is the first comparative study on the determinants of child support receipt in Europe, including Eastern and Central European countries. In particular, Eastern European countries have high divorce rates (OECD, 2021), which makes child support policy important for single parents in post-separation. Second, although factors associated with child support receipt have been examined in the United States (US), Columbia, and Peru (Cuesta and Meyer, 2014; Rios-Salas and Meyer, 2015) and in Asian countries (Chung and Kim, 2019), research evidence is scarce in Europe, especially in postsocialist countries (see Maslauskaitė and Tereškinas, 2017). Diverse cultural characteristics, such as gender roles, mothers' employment, and different institutional frameworks, can be expected to result in different patterns of child support receipt in less developed welfare states. Third, we examined the extent to which lone-mother families in European countries face similar barriers to child support receipt compared to their counterparts in quite different economic and social policy contexts. This is an important contribution, as most of the relevant literature focuses on studying the role of individual and family characteristics, without considering the context that may influence the experiences of lone mothers' receipt of child support. Where context is an influencing factor, our findings may provide support in finding potential solutions to the income vulnerability of lone mothers. Overall, our analysis has the potential to inform policy debates around child support policies in Europe, as it extends the empirical evidence available on the determinants of child support receipt and can assist with policy development. 


\section{Lone mothers in Europe: institutional context}

Cultural and policy contexts play an important role in cross-country differences relating to lone mothers' child support receipt via their effect on child support correlates (Cuesta and Meyer, 2012; Chung and Kim, 2019). Table 1 provides an overview of the relevant key characteristics in the 21 countries included in this study. The first three columns provide indicators concerning the need for child support policy. It could be expected that, in countries with a high proportion of lone mothers and a high child poverty rate, child support would be especially needed, as these families are economically vulnerable. The prevalence of children living in lone-parent families ranged from 7-9 percent of children in Greece and Poland to 25-28 percent in Belgium, Latvia, and Lithuania. The child poverty rates varied across these countries, with rates over 40 percent in Spain, Lithuania, and Luxembourg, and under 10 percent in Denmark.

Because child support regulations can embody expectations about the appropriate roles of mothers and fathers, two columns in Table 1 highlight gender issues. Increases in women's earnings accounted for a decline in child support in the 1980s (Robins, 1992), which has been suggested as being due to women's increased financial independence. Currently, across many countries, both parents' earnings play a key role in determining child support within current guidelines and child support formulas (Skinner et al., 2007). Thus, a high employment rate of lone mothers might correlate with low child support receipt. Table 1 shows a substantial variation in the employment rate of lone mothers, with a low employment rate of 58 percent in Greece and over 80 percent in Luxembourg, Portugal, and Sweden.

Broad agreement exists concerning the negative economic consequences of union dissolution for women (e.g., Mortelmans, 2020; Uunk, 2004; de Vaus et al., 2017). Child support can help 
equalize income between parents (Ha, Cancian and Meyer, 2018). Thus, a smaller gender wage gap can be associated with lower levels of child support receipt. The gender wage gap showed high levels of inequality in the Czech Republic, Estonia, Latvia, and the United Kingdom (UK), and relatively low levels in Belgium, Greece, and Italy.

\section{Table 1 here}

Using the categorization of Skinner et al. (2007) and Skinner and Hakovirta (2020), child support schemes have been identified as either agency, court-based, or hybrid schemes, depending on the role of the courts and public agencies in the operation of a country's scheme. Only two countries, Denmark and the UK, operate primarily agency schemes in which an administrative agency is responsible for the assessment, collection, and transfer of child support. Ten countries use courtbased schemes, in which the main responsibility for determining and enforcing child support orders lies within the judicial system. These systems are characterised as discretionary and, in most cases, they are less likely to apply standard rules and formulae when working out support liabilities. The other nine countries, Austria, Cyprus, Finland, Greece, Hungary, Ireland, Latvia, the Netherlands, and Sweden have hybrid schemes, in which both the judicial system and public agencies play a role in the main tasks of child support determination ${ }^{1}$.

How a child support scheme relates to child support receipt is uncertain. It is possible to consider that lone mothers who live in countries with hybrid child support schemes may be more likely to receive child support than in those with court-based systems. Unlike court-based schemes, hybrid

\footnotetext{
${ }^{1}$ See also European Judicial Network https://e-justice.europa.eu
} 
schemes offer the possibility of establishing child support arrangements outside the court. This feature may reduce the costs associated with the process of pursuing child support. For the same reason, it could be considered that lone mothers in countries with agency-based systems would be more likely to receive child support compared to lone mothers in countries with court-based systems. However, Hakovirta and Skinner (2020) found no obvious pattern in relation to the differing types of child support scheme adopted. Neither the regulations nor judicial decisionmaking in relation to child support calculations appear to involve any clearly discernible consistency, either within or across the scheme types.

\section{Previous research on the receipt of child support}

Previous comparative studies on child support have shown substantial cross-country differences in the receipt rates and amounts of child support received by lone mothers, while other research indicates that large numbers of non-resident fathers do not contribute to financial support for their children. LIS data (Luxembourg Income data) from around the year 2000 showed that the percentage of non-widowed lone parents receiving child support varied from 22 percent in the UK and 32 percent in the US, to up to 69 percent in Finland, with the highest amounts received in the US, the UK, and Canada (Skinner et al., 2007). The same LIS data from 2013 showed that in Finland, approximately 80 percent of lone mothers received child support compared with 42 percent in Spain, and approximately 33 percent in the UK, the US, and Germany. The US has been reported as having the highest median amount of child support (Hakovirta and Jokela, 2019). 
Several factors influence the likelihood of lone mothers receiving child support from non-resident fathers. At the individual level, lone mothers' educational level, age, employment status, income, marital status, and number of children affect their likelihood of receiving child support.

Mothers with high educational levels are more likely to receive child support in most countries (Chung and Kim, 2019, Cuesta and Meyer, 2012, Ríos-Salas and Meyer, 2014, Sorensen and Hill, 2004), for which there are three reasons. First, higher education may lead to an increased ability to navigate administrative and legal systems and greater incentive to seek child support orders. Highly educated mothers are also more likely to understand the legal requirements for obtaining child support and are more likely to seek legal advice (Chung and Kim, 2019). Second, mothers with higher educational levels are also more likely to invest material resources obtained from the children's fathers in their children (Bianchi et al., 2014). Third, assortative mating and marriage homogamy patterns predict a positive relationship between lone mothers' education and child support receipt (Garfinkel, Glei and McLanahan, 2002). Higher education of lone mothers may reflect a greater ability of non-resident fathers to pay child support because higher education usually implies higher earnings.

Findings concerning the effects of other sociodemographic factors associated with child support receipt, such as income and employment status, are contradictory. On the one hand, it might be thought that non-resident fathers would be more likely to pay child support when lone mothers are financially unable to care for their children, and the likelihood of such payments would promote the welfare of children (Chung and Kim, 2019). However, Cuesta and Meyer (2012) found that child support receipt was positively associated with lower levels of income among lone-mother families in Colombia. One potential explanation for this finding is that child support 
payments are based on need, and that, if fathers were "altruistic", child support would be paid in situations of need (Kim and Chung, 2020). On the other hand, lone mothers with greater economic resources are also better able to negotiate the legal system effectively to ensure receipt of child support. Hakovirta and Jokela (2019) found, when comparing six countries, that lone mothers in the highest income quintiles in Finland, Germany, and Spain were more likely to receive child support. Similarly, Skinner and Meyer (2006) found that lone mothers in the UK who were already relatively better off were more likely to receive child support and that lone mothers who received child support tended to receive similar median amounts, regardless of their income levels.

Empirical evidence concerning the effect of the employment status of parents is inconsistent, and the employment effect may be influenced by an educational effect. Being in employment may increase the likelihood of receiving child support, as working mothers may have greater possibilities of receiving child support, as they might have better resources to seek child support orders. On the other hand, being outside the labour market may mean that lone mothers need child support to financially support their children, or lone mothers receiving child support may be less likely to need work to financially support their children. For example, Cuesta et al. (2019) reported that lone mothers employed in Chile and Colombia were less likely to receive support.

Marital status plays a significant role in determining the probability of receiving child support. Divorced mothers are more likely to receive child support than mothers who have never been married (Cuesta and Meyer, 2012; Chung and Kim, 2019). It has been claimed that fathers are generally more involved with children born in marriage than in cohabitation (Maslauskaitè and Tereškinas, 2017). In addition, divorced parents may have stronger family ties, which can 
increase their willingness to pay. The lower likelihood of receiving child support among nevermarried mothers has also been explained by the fact that paternity must first be established to obtain a child support order, and some lone mothers may not want to do so (Cuesta and Meyer, 2012).

\section{Data, measures, and methods}

For the analysis, we used data from the EU-SILC, an annual household survey, designed and coordinated by Eurostat, and collected by national statistical authorities. The data provide crosssectional information on a wide range of social issues, primarily focussing on income, poverty, social exclusion, and living conditions. The advantages of the data include its comparability across many countries and relatively large sample sizes of lone mothers whose proportions in many surveys are otherwise limited.

For this study, we used a pooled dataset that included the years 2017 and 2018. We limited the analysis to lone mothers aged between 18 and 64 years who lived with at least one dependent child under 18 years of age and who were not widowed and not married. The total sample consisted of 9,596 lone-mother households (Table 2).

\section{Table 2 here}

\section{Outcome variable}

In our analysis, we conceptualised child support in the form of a cash payment made from one parent to another, following parental separation for the purpose of supporting children (International Network of Child Support Scholars, 2021). Formal child support involves a legal requirement established by a court or enforcement agency, while informal cash child support is a 
direct transfer from a non-resident parent to a child and involves no legal obligation. The EUSILC data do not provide information on the type of child support; thus, we examined both formal (compulsory) and informal (voluntary) child support received from non-resident fathers.

Our outcome variable was child support receipt, which was treated as a dichotomous variable (1 $=$ receives child support, $0=$ does not receive child support). Child support receipt refers to monetary child support and alimony received from another household during the previous year, and reported at the household level. The EU-SILC data do not distinguish between child support and alimony paid to an ex-spouse. However, this is not a serious limitation, as very few households receive alimony (see Meyer and $\mathrm{Hu}, 1999$ ). It should also be noted that the child support variable used here only included the amount paid by the father, but not the guaranteed support paid by the state in some countries. Thus, we compared only private child support arrangements. We discuss the possible limitations of this approach in the concluding section of this paper.

\section{Control variables}

To analyse the determinants of child support receipt, we included individual-level factors, such as age (continuous variable), marital status (dichotomous variable, divorced/never married), education $($ low $=$ high school education not completed, middle $=$ high school completed, high $=$ higher education), and employment status (employed/not employed). Household-level variables included income quintiles, measured using the pre-child support family income, which was obtained through subtracting the child support income from the equalised disposable income. The descriptive statistics of the background variables by child support receipt and country are presented in Appendix 1. 


\section{Analysis methods}

We first conducted a descriptive analysis to examine the differences in child support receipt and the amount of child support across countries, presented in purchasing power parity (ppp), and relative to the disposable income of lone mothers. Second, we ran logistic regression analyses using the pooled data for the 21 countries to examine factors associated with child support receipt. We also included interaction effects to account for possible cross-country variation in the association between lone mothers' characteristics and child support receipt.

\section{Results}

\section{Descriptive analysis}

Figure 1 depicts the proportion of lone mothers receiving child support in the 21 countries studied. We found significant variation in the extent of receipt, with rates varying from 75 per cent in the Czech Republic to 17 per cent in Luxembourg. In the Czech Republic, Denmark, Austria, Hungary, Cyprus, and Poland, over 50 per cent of lone mothers received child support. Approximately one in every two lone mothers in Finland, Portugal, Estonia, Latvia, Sweden, Belgium, Italy, the Netherlands, Spain, and Greece received child support. The lowest receipt rates were in the UK, France, Ireland, and Luxembourg, where approximately one-fifth of lonemother families received financial support from a non-resident parent.

Figure 2 displays the median yearly amount of child support for each country. The amount of child support was converted to euros using ppp. The average annual amounts received across countries ranged from 4710 euros in Austria to 512 euros in Hungary. Interestingly, median amounts did not correspond to the proportion of single parents receiving child support. For 
example, in Luxembourg, very few lone mother families received child support, but those receiving it obtained relatively high amounts, whereas the opposite was the case in the Czech Republic.

Figure 1 here

Child support formed a significant source of income for those lone mothers receiving it, particularly in Lithuania and Greece, where it may even be considered a lone mother's main source of income. In addition, in Southern European countries such as Italy, Spain, Portugal, and Cyprus, child support accounted for approximately 40-50 percent of total disposable household income. In Nordic countries (Finland, Denmark, and Sweden), Belgium, the UK, France, and Luxembourg, child support covered one-fifth or less of the total disposable household income of lone mothers.

Figure 2 here

Based on the information in Figures 1 and 2, we clustered countries into three different groups according to receipt rates and the levels of child support they provided, to obtain a general impression of what occurs among the countries. In the first group of countries, Austria, Cyprus, Denmark, and Finland had a high proportion of lone mothers receiving child support, with high levels of child support. In the second and largest group of countries that included most Eastern European countries such as the Czech Republic, Hungary, Poland, and Latvia, receipt rates were high, but the amount of child support received was low. In the third group of countries that 
included Greece, Spain, Italy, the UK, and France, less than 40 percent of lone mothers received child support, but those receiving it obtained relatively high amounts.

Next, we analysed the individual determinants of child support receipt and whether these differed across countries.

\section{Multivariate analysis: Determinants of child support receipt}

This section presents the results of multivariate and pooled regression analyses (Table 3). Our results accorded with the findings of previous studies, namely, that higher education and lone mothers' employment increased the likelihood of receiving child support, while lone mothers who had never been married or in union were less likely to receive child support. Furthermore, lone mothers in higher-income quintiles were more likely to receive child support than those in lower-income quintiles. The association between age, number of children, and child support receipt was not statistically significant.

\section{Table 3}

Previous studies have shown that there may be cross-country differences in terms of the effect of individual-level characteristics of lone mothers on the likelihood of receiving child support. Our findings showed that the association between marital status, educational level, employment status and income quintile, and child support receipt varied across countries (Figure 3).

Differences in the probability of receiving child support between divorced and never-married lone mothers were highest in countries with the lowest child support rates, such as Greece, the 
UK, France, and Luxembourg. In contrast, in countries where child support receipt rates were among the highest, such as Austria, the Czech Republic, Sweden, and Denmark, never-married lone mothers were equally or slightly more likely to receive child support compared to divorced lone mothers. Similarly, regarding marital status, the differences between educational levels were most marked in Luxembourg, the UK, and France, where higher-educated lone mothers were twice as likely to receive child support compared to lone mothers with lower educational levels. The smallest differences were again found in Austria, Denmark, Sweden, and Finland, where lower-educated lone mothers had a slightly higher likelihood of receiving child support compared to higher-educated lone mothers.

\section{Figure 3 here}

In Luxembourg, employed lone mothers were three times more likely to receive child support compared to those who were not employed, followed by Latvia, France, the Netherlands, Lithuania, and Portugal. In contrast, in Greece, Sweden, Cyprus, and Italy, lone mothers who were not employed were more likely to receive child support, while in the rest of the countries, the likelihood of receiving child support did not vary significantly by employment status.

While the pooled regression results (Table 3) showed a positive association between child support and income, the average marginal effects by country suggested significant cross-country variation in the association between child support and income quintiles. Interestingly, in most countries, lone mothers in the lowest quintiles were more likely to receive child support than those in the highest income quintiles. The differences were most marked in Greece, Lithuania, 
Sweden, and the Netherlands. In the UK, Hungary, Austria, the Czech Republic, and Denmark, the likelihood of receiving child support was approximately the same for the two income groups.

We also ran multilevel regression models (not shown here) to test the association between institutional factors (type of child support regime, male unemployment rate, and gender wage gap) and child support receipt. No statistically significant associations were found.

\section{Discussion and conclusions}

Using 2017-2018 EU-SILC survey data from 21 countries, this study extends current knowledge on the individual and family characteristics associated with child support receipt among lonemother families in Europe. As child support is an important income for lone mothers and contributes to children's wellbeing, it is likely to be useful to have a better understanding of the determinants associated with child support receipt in different cultural and institutional contexts.

This study provided important new findings. First, a substantial proportion of lone-mother families in the 21 European countries included in this study did not receive child support. Child support policies have been developed to ensure that following family breakdown, parents in separated families continue to financially support their children (Skinner et al., 2007; Skinner and Hakovirta, 2020). This obligation is enshrined within the United Nations Convention on the Rights of the Child, Article 27: 'State Parties shall take all appropriate measures to secure the recovery of maintenance for the child from the parents or other persons having financial responsibility for that child'. The analysis showed that in many countries, non-resident parents were not fulfilling their financial responsibilities. 
Second, there was significant variation in the extent of child support receipt across countries. The highest child support receipt rates were found in the Czech Republic, Denmark, and Austria. These countries also had a high gender wage gap, that is, men had higher earnings than women. The ideological and cultural persistence of the male breadwinner model may put greater emphasis on fathers' economic obligations toward their children. A large gender wage gap may continue to position mothers as primary carers and child support payers as breadwinners, leading to an increase in child support receipt. This may also result in child support orders in post-separation to equalise the incomes of ex-partners. Our results also indicated that in countries where the need for child support was high, for instance, due to the high prevalence of child poverty among lonemother households, lone mothers did not seem to benefit from child support.

Based on our descriptive findings on receipt and amount of child support, we categorised the countries into three groups. Austria, Cyprus, Denmark, and Finland had a high proportion of lone mothers receiving child support with high levels of child support payments. Many countries particularly in Eastern Europe, including the Czech Republic, Hungary, Poland, and Latvia, had high receipt rates but low amounts of child support being received. Other countries, including Greece, Spain, Italy, the UK, and France, had less than 40 percent of lone mothers receiving child support, but those receiving it obtained relatively high amounts.

Third, we found cross-country variation in the association between individual-level and household-level characteristics and child support receipt. Socioeconomic differences in child support receipt were generally most marked in countries with low child support receipt. For example, in Luxembourg, employed lone mothers were three times more likely to receive child support than unemployed lone mothers, and divorced lone mothers were nine times more likely 
to receive child support than never-married lone mothers. However, in most countries, lone mothers in the lowest quintiles were more likely to receive child support than those in the highest income quintiles. The largest differences between income quintiles were found both in countries with high child support coverage (Sweden) and in those with low rates of child support receipt (Greece and Lithuania). In Nordic countries, lower-educated lone mothers were more likely to receive child support, whereas the opposite was the case in France, the UK, and Luxembourg. In other countries, differences between educational levels were less marked.

In general, socioeconomic factors among lone mothers exerted a strong influence on child support receipt. Low socioeconomic status was a common barrier to child support receipt in most countries, and lone mothers faced similar challenges in pursuing child support. It may be that when fathers are disadvantaged, they cannot provide economic resources for their children. Thus, it seems that current child support policies work for families with more resources and less well for already disadvantaged families. In countries with guaranteed child support schemes, lone mothers are in a better position, as the state provides support where a non-resident father does not pay child support.

Since the role of contextual factors in determining child support receipt among lone-mother families remains largely unknown, we also tested the association between several country-level factors, including the type of child support regime, male unemployment rate, gender wage gap, and child support receipt. No statistically significant associations were found, which is why we excluded contextual factors from the final analyses. While our results only showed variation in child support receipt at the individual level, country-level determinants need to be considered in future research, for example, in terms of how welfare state institutions, such as child support 
enforcement, predict child support receipt in various countries. The different institutional arrangements found in child support policies, that is, whether court-based, agency-based, or a hybrid system, did not appear to influence child support receipt, with no clear pattern or consistency found in terms of the regulations or judicial decision-making in relation to child support determination, either within or across the scheme types. This finding accorded with those of previous studies (Hakovirta and Skinner, 2020).

This study's results should be interpreted considering the following limitations. First, the EUSILC data were not designed for child support research, thus limiting the extent to which the role of various child support policy schemes could be examined. For example, while the focus of our analysis was on private arrangements, it would have been interesting to include guaranteed child support that is paid by the state in some of the countries in the analysis. Including guaranteed child support would inevitably show a higher proportion of lone mothers receiving child support (Hakovirta and Jokela, 2019; Hakovirta and Eydal, 2020).

Another limitation was that not all factors could be controlled that may be related to child support receipt. For example, prior research suggests that in addition to lone mothers' characteristics, child support receipt is dependent on the circumstances of fathers (Hakovirta et al., 2019; Maslauskaitė and Tereškinas, 2017; Hakovirta et al., 2019). While we acknowledge that nonresident parents' characteristics and their ability to contribute to their children's lives would be important to consider, very few comparative data sets, including the EU-SILC, have information on non-resident fathers that could be linked to lone-mother households. Furthermore, child support payers' new partnerships and children's contact with non-resident parents may influence the likelihood of child support receipt. Remarriage of non-resident fathers has been found to often 
decrease motivation and the ability to pay child support (Hakovirta et al., 2019), while some lowincome fathers prefer paying informal support over formal support (Vogel, 2020) Our data did not include frequency of contact, which has been shown to correlate with child support receipt (Maluskaite and Tereškinas, 2017). Moreover, shared care arrangements where children live with both parents for approximately equal amounts of time have increased in many countries (Steinbach et al., 2020). In these families, parents often make private arrangements, and child support is not always required (Hakovirta and Skinner, 2021), which may result in a lower proportion of lone-mother families receiving child support.

Beyond these general difficulties and limitations, this study showed that lone mothers in Europe face barriers to child support, which might affect their economic well-being. This finding has implications for the development of child support policies. First, there is no easy solution for non-compliance with child support if non-resident fathers have no financial capacity to pay. A public guarantee of a minimum amount of support has been suggested in the U.S as it may help non-resident fathers not to have to pay beyond their current means (Cancian and Meyer, 2018). Second, having been formerly married is a significant predictor of child support receipt. However, cohabitation has become a popular living arrangement among families with children. While child support policies treat married and cohabitant partners in an equivalent way in most countries (Skinner et al., 2007), our results highlight the need to promote policies supporting continuity concerning cohabited fathers' financial commitments in post-separation. For example, shared parental leave tends to increase fathers' involvement in post-separation (Duvander and Jans, 2009), as fathers who were more involved parents prior to separation tend to have more frequent contact after separation (Haux and Platt, 2021). Increased efforts to help fathers maintain bonds with their children are more likely to lead them to provide financial support. 


\section{References:}

Baughman, R. A. (2017). The impact of child support on child health. Review of Economics of Household, 15(1), 69-91.

Bengtsson, M., de la Porte, C., \& Jacobsson, K. (2017). Labour market policy under conditions of permanent austerity: Any sign of social investment? Social Policy and Administration, 51(2), 367-388.

Bernandi, L., Mortelmans, D., \& Larenza, O. (2018). Changing lone parents, changing life courses. In L. Bernandi, \& D. Mortelmans (Eds.), Lone parenthood in the life course (pp. 1-26). Life Course Research and Social Policies. Springer Open.

Bianchi, S., Cohen, P. N., Raley, S., \& Nomaguchi, K. (2004). Inequality in parental investment in child-rearing: Expenditures, time, and health. In K. Neckerman (Ed.), Social inequality (pp. 189-220). New York: Sage.

Bonoli, G. (2007). "Too narrow and too wide at once": The welfare state as a dependent variable in policy analysis. In J. Clasen \& N. Siegel (Eds.), Investigating welfare state change: The 'dependent variable' problem in comparative analyses (pp. 24-39). Cheltenham: Edward Elgar.

Bradshaw, J., Keung, A., \& Chzhen, Y. (2018). Cash benefits and poverty in single-parent families. In R. Nieuwenhuis and L. Maldonado (Eds.), The triple bind of single-parent families: resources, employment and policies to improve well-being (pp. 337-358). Bristol: Policy Press.

Cancian, M., \& Meyer, D. R. (2018). Reforming policy for single-parent families to reduce child poverty. Journal of the Social Sciences, 4(2), 91-112.

Cancian, M., Yang, M. Y., \& Shook Slack, K. (2013). The effect of additional child support income on the risk of child maltreatment. Social Service Review, 87(3), 417-437. 
Case, A., Lin, I. F., \& McLanahan, S. (2003). Explaining trends in child support: Economic, demographic and policy effects. Demography, 40(1), 171-189.

Chung, Y., \& Kim, Y. (2019). Do cultural and policy contexts matter to child support policy? A case study of child support receipt in Korea and the United States. Children and Youth Services Review, 96(1), 237-249.

Corden, A. (1999). Making child support regimes work. London: Family Policy Studies Centre.

Cuesta, L., Hakovirta, M., Jokela, M., \& Malebera, H. (2019). Who receives child support in Latin America? A comparative analysis of seven countries. Paper for the Society for Social Work and Research 23rd annual conference, January 16-20 2019, San Francisco, CA.

Cuesta, L., Hakovirta, M., \& Jokela, M. (2018). The antipoverty effectiveness of child support: empirical evidence for Latin American countries. Social Policy and Administration, 52(6), 12331251.

Cuesta, L., \& Meyer, D. R. (2012). Child support receipt: Does context matter? A comparative analysis of Colombia and the United States. Children and Youth Services Review, 34(9), 18761883.

Duvander, A. Z., \& Jans, A. C. (2009). Consequences of fathers' parental leave use: Evidence from Sweden. Finnish Yearbook of Population Research, 44, 49-62

Eurostat. (2021). Gender wage gap. Available at: https://ec.europa.eu/eurostat/statisticsexplained/index.php/Gender_pay_gap_statistics (Accessed: 22 March 2021)

Garfinkel, I., Glei, D., \& McLanahan, S. (2002). Assortative mating among unmarried parents: Implications for ability to pay child support. Journal of Population Economics, 15, 417-432. 
Ha, Y., Cancian, M., \& Meyer, D. R. (2018). Child support and income inequality. Poverty \& Public Policy, 10(2), 147-158.

Hakovirta, M. (2011). Child support and child poverty: a comparative analysis. Journal of Poverty and Social Justice, 19(3), 249-262.

Hakovirta, M., \& Jokela, M. (2019). Contribution of child maintenance to lone mothers' income in five countries. Journal of European Social Policy, 29(2), 257-272.

Hakovirta, M. Meyer, D. R., \& Skinner, C. (2019). Does paying child support impoverish fathers in the United States, Finland and the United Kingdom, in Children and Youth Services Review, 106, [104485]. https://doi.org/10.1016/j.childyouth.2019.104485

Hakovirta, M., \& Skinner, C. (2021). Shared physical custody and child maintenance arrangements: A comparative analysis of 13 countries. In Laura Bernardi \& Dimitri Mortelmans (Eds.), Interdisciplinary insights on shared physical custody. New York: Springer.

Hanson, T. L., Garfinkel, I., Mclanahan, S. S., \& Miller, C. (1996). Trends in child support outcomes. Demography, 33(4), 483-496.

Haux, T., \& Platt, L. (2021). Fathers' involvement with their children before and after separation. European Journal of Population, 37, 151-177.

Huang, C. C. (2009). Trends in child support from 1994 to 2004: Does child support enforcement work? Journal of Policy Practice, 9 (1), 36-53

International Network of Child Support Scholars. (2019). Glossary. INCSS. Available at: https://www.incss.org/glossary (Accessed: 12 June 2019) 
Kim, Y., \& Chung, Y. (2020). Child support receipt among divorced mothers in Korea: Changes after the 2007 policy reform. Children and Youth Services Review, 119, [105446]. https://doi.org/10.1016/j.childyouth.2020.105446

Maldonado, L., \& Nieuwenhuis, R. (2015). Family policies and single parent poverty in 18 OECD countries, 1978-2008. Community, Work \& Family, 18(4), 395-415.

Maslauskaitė, A., \& Tereškinas, A. (2017). Involving nonresident Lithuanian fathers in childrearing: The negative impact of income inequalities and sociolegal policies. Men and Masculinities, 20(5), 609-629.

Meyer, D. R., \& Hu, M., (1999). A note on the antipoverty effectiveness of child support among mother-only families. Journal of Human Resources, 34(1), 225-234.

Nepomnyaschy, L., Magnuson, K., \& Berger, L. M. (2012). Child support and young children's development. The Social Service Review, 86(1), 3-35.

Nepomnyaschy, L., Miller D., Garasky, S., \& Nanda, N. (2014). Nonresident fathers and child food insecurity: Evidence from longitudinal data. Social Service Review, 88(1), 92-133.

Nieuwenhuis, R. (2020). The situation of single parents in the EU. European parliament. Available at:

https://www.europarl.europa.eu/thinktank/en/document.html?reference=IPOL_STU(2020)65987 $\underline{0}$ (Accessed 19 February 2021)

Organisation for Economic Co-operation and Development. (2021). Family policy database. Available at: http://www.oecd.org/els/family/database.htm (Accessed 19 February 2021)

Ríos-Salas, V., \& Meyer, D. R. (2014). Single mothers and child support receipt in Peru. Journal of Family Studies, 20(3), 298-310. 
Robins, P. K. (1992). Why did child support award levels decline from 1978 to 1985 ? Journal of Human Resources, 27(1), 362-379.

Skinner, C. Bradshaw, J., \& Davidson, J. (2007). Child support policy: An international perspective. (Report No. 405). United Kingdom: Department for Work and Pensions.

Skinner, C., Cook, K., \& Sinclair, S. (2017). The potential of child support to reduce lone mother poverty: comparing population survey data in Australia and the UK. Journal of Poverty and Social Justice, 25(1), 79-94.

Skinner, C. Hakovirta, M. (2020). Separated families and child support policies in times of social change: A comparative analysis. In R. Nieuwenhuis \& W. Van Lanckers (Eds.), The Palgrave Handbook of Family Policy (pp. 267-301). London: Palgrave Macmillan.

Sorensen, E., \& Hill, A. (2004). Single mothers and their child-support receipt: How well is child support enforcement doing? Journal of Human Resources, 39(1),135154.

Steinbach, A., Augustijn, L., \& Corkadi, G. (2020). Joint physical custody and adolescents' life satisfaction in 37 North American and European countries', Family Process, 60, 145-158.

Uunk, W. (2004). The economic consequences of divorce for women in the European Union: The impact of welfare state arrangements. European Journal of Population, 20(3), 251-285.

de Vaus, D, Gray, M, Qu, L, \& Stanton, D. (2017). The economic consequences of divorce in six OECD countries. Australian Journal of Social Issues. 52, 180-199.

Vnuk, M. (2019). Keeping mum: Characteristics and family dynamics of mothers who are liable to pay child support in Australia. Australian and New Zealand Journal of Family Therapy, 40, 127-142. 
Table 1. Situation of lone mothers in 21 European countries

\begin{tabular}{|c|c|c|c|c|c|}
\hline Country & $\begin{array}{l}\text { Proportion of } \\
\text { children living } \\
\text { with lone } \\
\text { parents, } 2019\end{array}$ & $\begin{array}{l}\text { Child poverty } \\
\text { rate for lone } \\
\text { parent } \\
\text { households } \\
\text { with at least } \\
\text { one child, } \\
20162\end{array}$ & $\begin{array}{l}\text { Employment } \\
\text { rate of lone } \\
\text { mothers with at } \\
\text { least one child } \\
\text { aged } 0-3\end{array}$ & $\begin{array}{l}\text { Gender wage gap } \\
2018\end{array}$ & $\begin{array}{l}\text { Child } \\
\text { support } \\
\text { regime }\end{array}$ \\
\hline Austria & 14,1 & 24,1 & 75,2 & 20 & Hybrid \\
\hline Belgium & 24,9 & 32,2 & 61,3 & 5,8 & Court \\
\hline Cyprus & 13,6 & N/A & 71,5 & 10,4 & Hybrid \\
\hline Czech Republic & 13,6 & 32,8 & 66,8 & 20,1 & Court \\
\hline Denmark & 20,6 & 8,2 & 75,4 & 14,6 & Agency \\
\hline Estonia & 14,6 & 21,6 & 79,1 & 21,8 & Court \\
\hline Finland & 14,5 & 14,9 & 72,4 & 17,1 & Hybrid \\
\hline France & 22,5 & 25,9 & 66,4 & 15,8 & Court \\
\hline Greece & 7,4 & 27,7 & 58,5 & 7,9 & Hybrid \\
\hline Hungary & 20,8 & 34,5 & 74,9 & 12,2 & Hybrid \\
\hline Ireland & 21,8 & 34,5 & 61,4 & $\ldots$ & Hybrid \\
\hline Italy & 14,7 & 37,0 & 63,6 & 3,9 & Court \\
\hline Latvia & 27,8 & 34,5 & 77,6 & 19,6 & Hybrid \\
\hline Lithuania & 26,9 & 45,8 & 78,0 & 14 & Court \\
\hline Luxembourg & 14,1 & 41,4 & 86,0 & 1,4 & Court \\
\hline Netherlands & 12,4 & 29,5 & 66,9 & 14,7 & Hybrid \\
\hline Poland & 9,0 & 16,4 & 65,4 & 8,5 & Court \\
\hline Portugal & 20,0 & 30,2 & 80,9 & 8,9 & Court \\
\hline Spain & 15,6 & 40,2 & 64,9 & 11,9 & Court \\
\hline Sweden & 20,7 & 25,8 & 80,8 & 12,1 & Hybrid \\
\hline UK & 21,6 & 23,2 & 67,4 & 19,8 & Agency \\
\hline
\end{tabular}

Sources: Skinner et al., 2007; Nieuwenhuis, 2020; OECD Family Policy Database, 2020; Eurostat, 2021; Skinner \&

Hakovirta, 2020 
Table 2. Descriptive statistics: characteristics of lone mother families in 2017-2018.

\begin{tabular}{lccc}
\hline & Lone mothers (N) & $\begin{array}{c}\text { Proportion of lone parents of } \\
\text { all households with } \\
\text { dependent children (\%) }\end{array}$ & $\begin{array}{c}\text { Proportion of lone } \\
\text { parent households with } \\
\text { female head (\%) }\end{array}$ \\
\hline Austria (AT) & 376 & 10 & 90 \\
Belgium (BE) & 503 & 17 & 83 \\
Cyprus (CY) & 224 & 9 & 88 \\
Czech Re (CZ) & 504 & 13 & 92 \\
Denmark (DK) & 301 & 23 & 79 \\
Estonia (EE) & 314 & 14 & 92 \\
Greece (EL) & 469 & 5 & 91 \\
Spain (SP) & 577 & 9 & 89 \\
Finland (FI) & 416 & 16 & 79 \\
France (FR) & 769 & 17 & 78 \\
Hungary (HU) & 311 & 13 & 90 \\
Ireland (IR) & 234 & 17 & 91 \\
Italy (IT) & 978 & 12 & 80 \\
Lithuania (LT) & 260 & 20 & 91 \\
Luxembourg (LU) & 203 & 11 & 88 \\
Latvia (LV) & 415 & 17 & 84 \\
Netherlands (NL) & 636 & 13 & 92 \\
Poland (PL) & 488 & 5 & 88 \\
Portugal (PT) & 640 & 12 & 62 \\
Sweden (SE) & 272 & 20 & 89 \\
United Kingdom (UK) & 573 & 19 & - \\
Total & $\mathbf{9 5 9}$ & - & 90 \\
\hline
\end{tabular}


Table 3. Logistic regression on child support receipt. Odds ratios (ORs) and confidence intervals (Cis).

\section{Model 1}

Model 2

Odds ratio CI $(95 \%) \quad$ Odds ratio $\quad$ CI $(95 \%)$

\begin{tabular}{|c|c|c|c|c|c|c|}
\hline Age & 1.00 & 0.99 & 1.01 & 0.01 & 0.99 & 1.01 \\
\hline \multicolumn{7}{|l|}{ Education (low) } \\
\hline Medium & 1.04 & 0.85 & 1.27 & 1.21 & 0.99 & 1.47 \\
\hline High & 1.18 & 0.96 & 1.46 & $1.66 * * *$ & 1.34 & 2.07 \\
\hline Never married & $0.42 * * *$ & 0.36 & 0.49 & $0.44 * * *$ & 0.37 & 0.51 \\
\hline Employed & 0.97 & 0.82 & 1.15 & $1.43 * * *$ & 1.19 & 1.72 \\
\hline $\begin{array}{l}\text { Number of children } \\
\text { (one) }\end{array}$ & & & & 0.92 & 0.84 & 1.01 \\
\hline \multicolumn{7}{|l|}{$\begin{array}{l}\text { Income quintile } \\
\text { (lowest) }\end{array}$} \\
\hline 2 & & & & $0.47 * * *$ & 0.38 & 0.59 \\
\hline 3 & & & & $0.36 * * *$ & 0.28 & 0.46 \\
\hline 4 & & & & $0.34 * * *$ & 0.27 & 0.43 \\
\hline Highest & & & & $0.22 * * *$ & 0.17 & 0.29 \\
\hline
\end{tabular}

\begin{tabular}{lrrrrrr} 
Constant $3.00 * * *$ & 1.78 & 5.09 & $5.16 * * *$ & 2.82 & 9.45 \\
\hline
\end{tabular}

Note: $* \mathrm{p}<0.05, * * \mathrm{p}<0.01, * * * \mathrm{p}<0.001$

Model 1 includes individual-level characteristics, while Model 2 includes individual-level and householdlevel characteristics. The models were controlled for each country. 


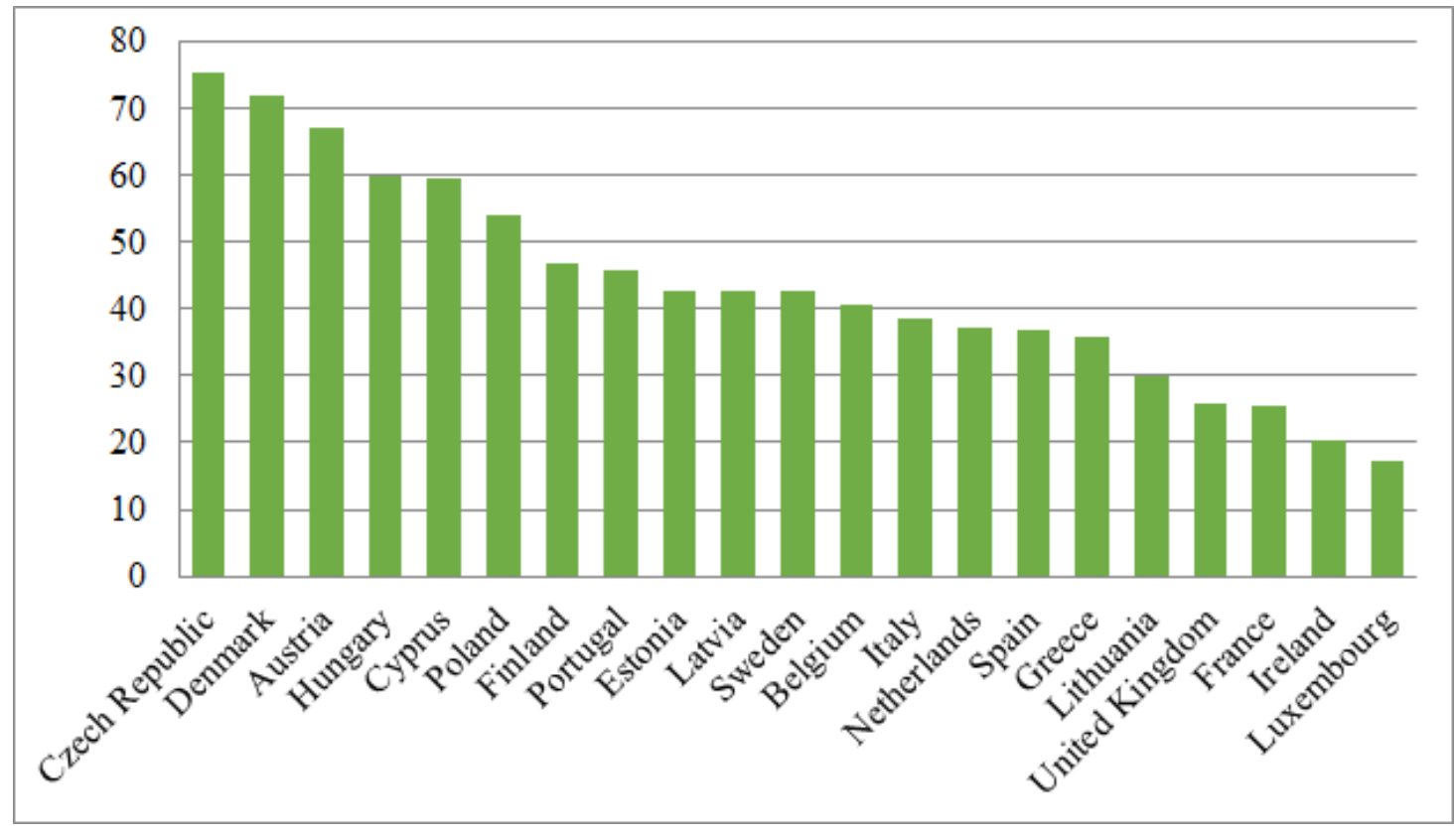

Figure 1. Proportion of lone mother households receiving child support in 21 European countries in 2017-2018. 


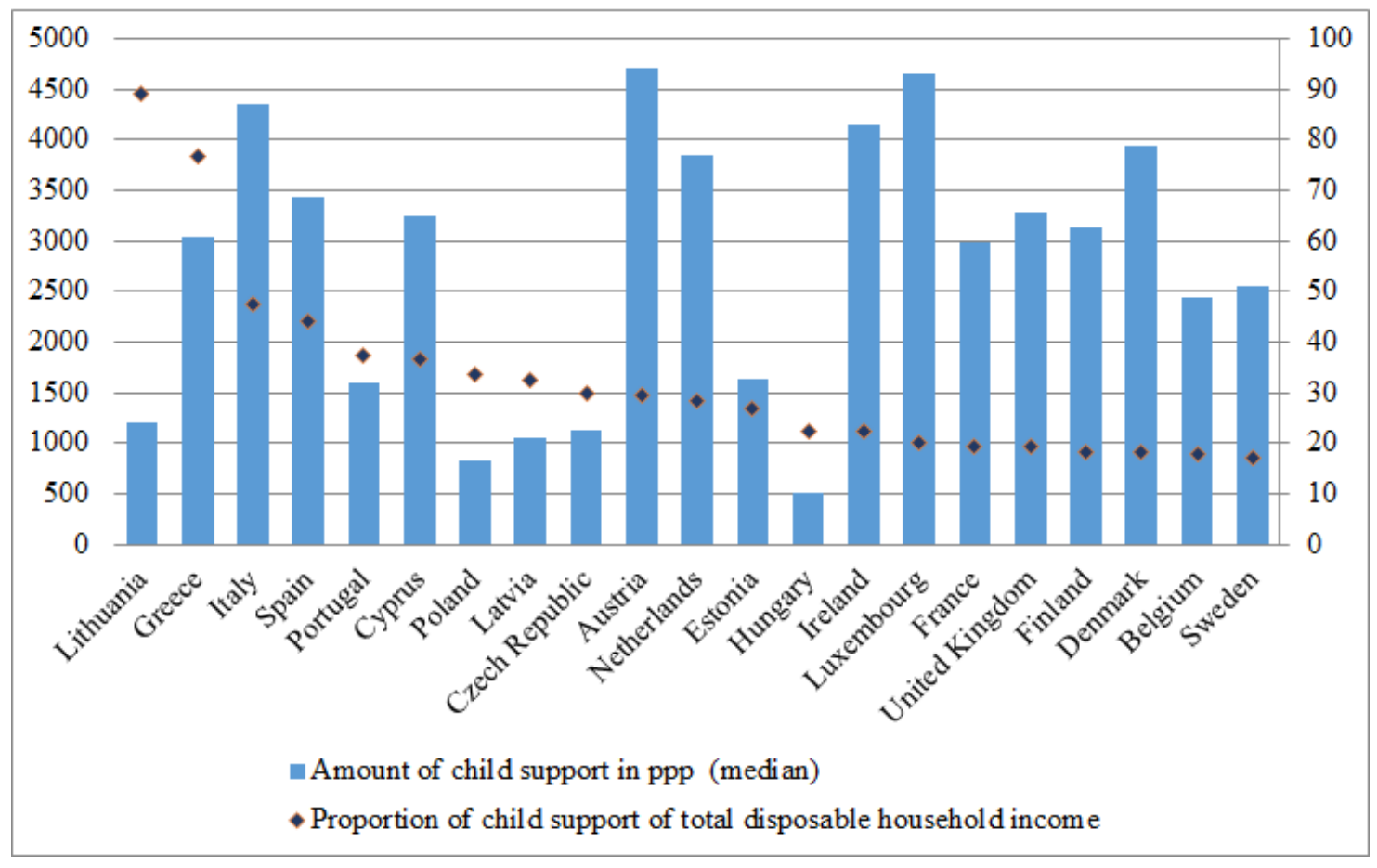

Figure 2. Median amount of child support received by lone mothers and the proportion of child support of lone mother households' disposable income in 21 European countries in 2017-2018. 


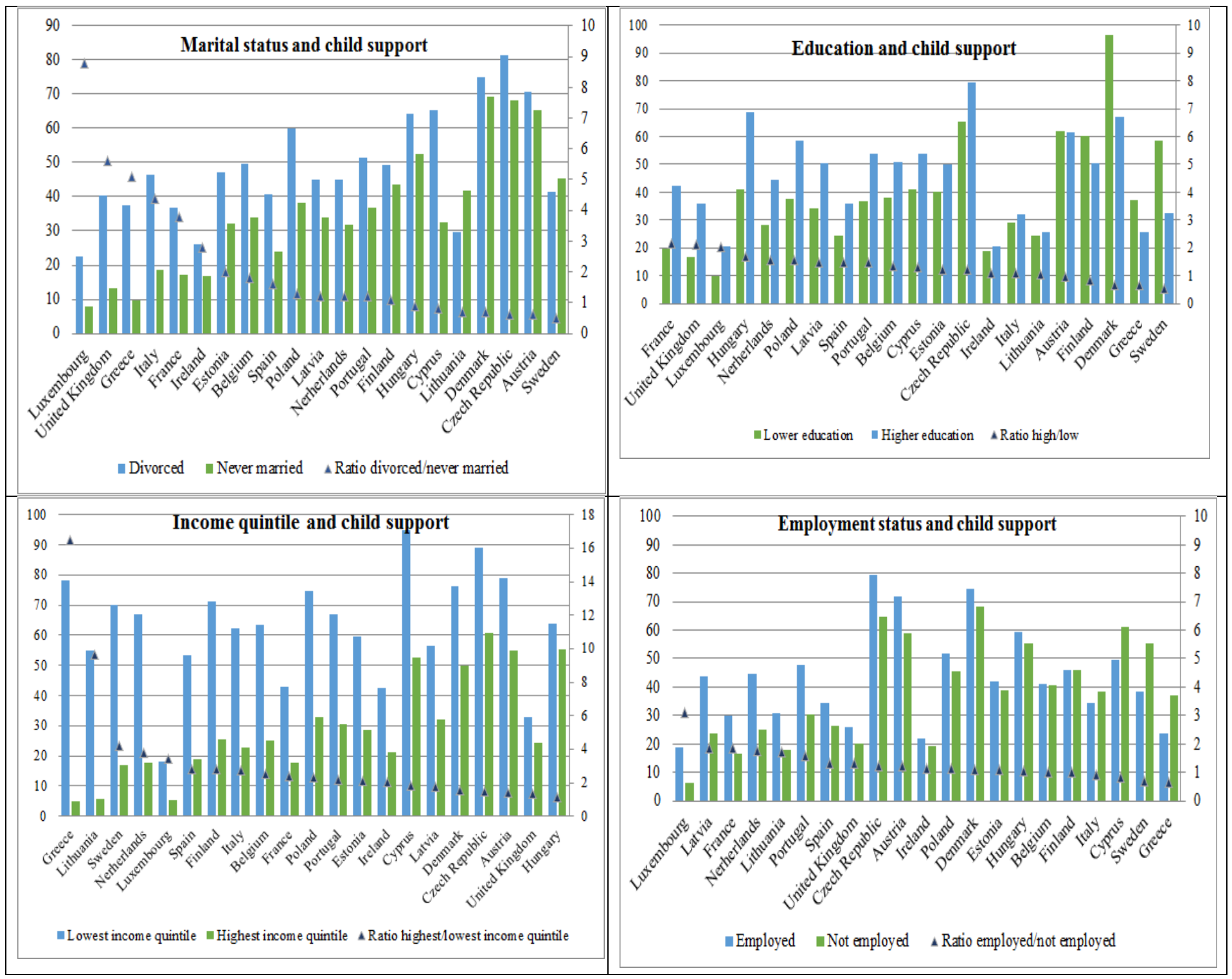

Figure 3. Predicted probabilities for child support receipt by marital status, education, income quintile and employment status. All models were controlled for age, marital status, education, employment, number of children, and income quintile. 'Divorced' refers to dissolution of a legal union. 
Appendix 1a. Characteristics of lone mothers receiving child support by country in 2017-2018, \%

\begin{tabular}{|c|c|c|c|c|c|c|c|c|c|c|c|c|c|c|c|c|c|c|c|c|c|c|}
\hline & AT & BE & $\mathbf{C H}$ & CY & $\mathbf{C Z}$ & DK & EE & EL & ES & FI & FR & $\mathbf{H U}$ & IE & IT & LT & $\mathbf{L U}$ & $\mathbf{L V}$ & NL & PL & PT & SE & UK \\
\hline \multicolumn{23}{|l|}{ Age } \\
\hline 18-24 & 2 & 1 & 0 & 0 & 0 & 1 & 0 & 0 & 1 & 0 & 1 & 2 & 8 & 1 & 2 & 0 & 1 & 1 & 2 & 0 & 1 & 9 \\
\hline $25-34$ & 23 & 14 & 12 & 38 & 21 & 10 & 39 & 5 & 7 & 30 & 14 & 26 & 24 & 11 & 30 & 17 & 24 & 11 & 28 & 16 & 25 & 28 \\
\hline $35-44$ & 42 & 43 & 42 & 53 & 60 & 55 & 33 & 52 & 55 & 47 & 46 & 58 & 48 & 45 & 41 & 46 & 54 & 42 & 54 & 56 & 42 & 34 \\
\hline $45+$ & 33 & 43 & 46 & 9 & 19 & 34 & 28 & 43 & 38 & 23 & 39 & 14 & 20 & 43 & 26 & 37 & 21 & 46 & 16 & 28 & 31 & 28 \\
\hline \multicolumn{23}{|l|}{ Education } \\
\hline Low & 15 & 27 & 7 & 7 & 8 & 18 & 9 & 14 & 28 & 14 & 17 & 15 & 20 & 22 & 5 & 26 & 10 & 20 & 6 & 39 & 32 & 18 \\
\hline Medium & 59 & 35 & 52 & 52 & 73 & 40 & 40 & 54 & 29 & 46 & 37 & 58 & 40 & 55 & 52 & 44 & 46 & 48 & 52 & 30 & 36 & 38 \\
\hline High & 26 & 38 & 42 & 42 & 19 & 42 & 51 & 32 & 44 & 40 & 46 & 26 & 40 & 23 & 43 & 30 & 44 & 32 & 42 & 31 & 32 & 44 \\
\hline Employed & 73 & 56 & 80 & 61 & 79 & 67 & 84 & 55 & 76 & 64 & 83 & 79 & 49 & 79 & 77 & 89 & 83 & 77 & 74 & 87 & 64 & 72 \\
\hline Never married/ in union & 42 & 35 & 26 & 11 & 35 & 44 & 42 & 2 & 18 & 42 & 42 & 26 & 51 & 17 & 24 & 18 & 29 & 38 & 21 & 28 & 45 & 55 \\
\hline \multicolumn{23}{|l|}{ Number of children } \\
\hline One & 50 & 38 & 47 & 47 & 59 & 48 & 52 & 48 & 54 & 47 & 41 & 43 & 28 & 50 & 48 & 60 & 59 & 35 & 55 & 52 & 44 & 48 \\
\hline Two & 41 & 45 & 45 & 32 & 36 & 41 & 38 & 35 & 39 & 31 & 46 & 46 & 38 & 42 & 42 & 32 & 28 & 54 & 36 & 41 & 34 & 36 \\
\hline Three or more & 9 & 17 & 8 & 21 & 5 & 10 & 10 & 17 & 7 & 22 & 12 & 10 & 33 & 8 & 10 & 8 & 13 & 11 & 9 & 7 & 21 & 16 \\
\hline \multicolumn{23}{|l|}{ Income quintile } \\
\hline Lowest & 23 & 27 & 31 & 32 & 23 & 20 & 27 & 45 & 28 & 29 & 29 & 21 & 37 & 32 & 33 & 18 & 26 & 33 & 28 & 28 & 29 & 19 \\
\hline 2 & 22 & 17 & 28 & 21 & 21 & 20 & 21 & 26 & 23 & 27 & 20 & 22 & 5 & 16 & 19 & 17 & 23 & 17 & 21 & 22 & 30 & 19 \\
\hline 3 & 20 & 18 & 15 & 9 & 20 & 23 & 21 & 12 & 16 & 15 & 21 & 16 & 20 & 17 & 22 & 34 & 17 & 18 & 17 & 20 & 14 & 19 \\
\hline 4 & 17 & 22 & 12 & 15 & 19 & 22 & 16 & 13 & 20 & 17 & 14 & 19 & 16 & 19 & 21 & 22 & 17 & 21 & 19 & 15 & 15 & 18 \\
\hline Highest & 18 & 16 & 13 & 22 & 18 & 15 & 15 & 4 & 13 & 12 & 16 & 22 & 21 & 15 & 6 & 9 & 18 & 11 & 16 & 16 & 11 & 25 \\
\hline
\end{tabular}

Source: European Union Statistics on Income and Living Conditions 2017-2018. 
Appendix 1b. Characteristics of lone mothers not receiving child support by country in 2017-2018, \%

\begin{tabular}{|c|c|c|c|c|c|c|c|c|c|c|c|c|c|c|c|c|c|c|c|c|c|c|}
\hline & AT & $\mathbf{B E}$ & $\mathbf{C H}$ & CY & $\mathrm{CZ}$ & DK & $\mathbf{E E}$ & EL & $\mathbf{E S}$ & FI & FR & HU & IE & IT & LT & $\mathbf{L U}$ & $\mathbf{L V}$ & NL & PL & PT & SE & UK \\
\hline \multicolumn{23}{|l|}{ Age } \\
\hline $18-24$ & 1 & 3 & 1 & 11 & 1 & 2 & 0 & 0 & 1 & 4 & 2 & 4 & 1 & 1 & 8 & 3 & 2 & 3 & 2 & 1 & 0 & 7 \\
\hline $25-34$ & 24 & 25 & 25 & 25 & 26 & 14 & 23 & 5 & 11 & 21 & 26 & 9 & 35 & 16 & 28 & 24 & 31 & 21 & 29 & 23 & 22 & 30 \\
\hline $35-44$ & 44 & 43 & 41 & 46 & 49 & 58 & 51 & 51 & 46 & 39 & 44 & 61 & 39 & 46 & 51 & 42 & 41 & 41 & 57 & 50 & 45 & 37 \\
\hline $45+$ & 32 & 29 & 33 & 17 & 24 & 26 & 25 & 44 & 42 & 36 & 28 & 26 & 25 & 37 & 13 & 32 & 26 & 34 & 12 & 27 & 33 & 26 \\
\hline \multicolumn{23}{|l|}{ Education } \\
\hline Low & 19 & 27 & 36 & 7 & 18 & 2 & 8 & 8 & 34 & 8 & 20 & 26 & 23 & 21 & 9 & 33 & 12 & 26 & 11 & 44 & 13 & 29 \\
\hline Medium & 43 & 41 & 23 & 40 & 64 & 33 & 46 & 47 & 22 & 53 & 54 & 56 & 33 & 49 & 42 & 42 & 55 & 46 & 55 & 32 & 35 & 43 \\
\hline High & 38 & 32 & 40 & 53 & 19 & 64 & 46 & 45 & 44 & 39 & 26 & 18 & 44 & 30 & 49 & 25 & 33 & 28 & 34 & 24 & 52 & 28 \\
\hline Employed & 65 & 62 & 67 & 75 & 68 & 67 & 87 & 77 & 72 & 67 & 74 & 80 & 56 & 88 & 70 & 78 & 76 & 60 & 73 & 81 & 81 & 65 \\
\hline $\begin{array}{l}\text { Never } \\
\text { married/ in } \\
\text { union }\end{array}$ & 47 & 50 & 46 & 31 & 50 & 53 & 59 & 14 & 35 & 50 & 68 & 36 & 65 & 44 & 18 & 40 & 42 & 58 & 40 & 42 & 44 & 68 \\
\hline \multicolumn{23}{|l|}{$\begin{array}{l}\text { Number of } \\
\text { children }\end{array}$} \\
\hline One & 68 & 50 & 54 & 66 & 58 & 65 & 69 & 58 & 62 & 55 & 49 & 45 & 41 & 61 & 48 & 54 & 63 & 52 & 57 & 52 & 44 & 44 \\
\hline Two & 20 & 37 & 26 & 29 & 30 & 31 & 24 & 37 & 30 & 30 & 39 & 39 & 39 & 33 & 38 & 34 & 30 & 35 & 32 & 44 & 48 & 36 \\
\hline $\begin{array}{l}\text { Three or } \\
\text { more }\end{array}$ & 11 & 13 & 20 & 5 & 12 & 4 & 7 & 6 & 8 & 15 & 13 & 16 & 21 & 7 & 13 & 12 & 7 & 14 & 11 & 4 & 8 & 20 \\
\hline \multicolumn{23}{|l|}{$\begin{array}{l}\text { Income } \\
\text { quintile }\end{array}$} \\
\hline Lowest & 14 & 15 & 0 & 3 & 11 & 20 & 15 & 6 & 15 & 13 & 17 & 20 & 16 & 12 & 14 & 20 & 16 & 13 & 11 & 14 & 13 & 21 \\
\hline 2 & 16 & 22 & 4 & 18 & 18 & 21 & 20 & 17 & 18 & 14 & 20 & 16 & 24 & 23 & 22 & 21 & 18 & 22 & 19 & 19 & 12 & 21 \\
\hline 3 & 20 & 21 & 30 & 39 & 20 & 12 & 19 & 24 & 22 & 25 & 20 & 26 & 20 & 21 & 18 & 17 & 23 & 21 & 24 & 20 & 24 & 20 \\
\hline 4 & 26 & 19 & 34 & 24 & 23 & 15 & 24 & 24 & 20 & 23 & 22 & 21 & 22 & 20 & 20 & 20 & 22 & 19 & 21 & 25 & 23 & 21 \\
\hline Highest & 24 & 23 & 32 & 17 & 27 & 32 & 23 & 29 & 24 & 26 & 21 & 17 & 19 & 23 & 26 & 21 & 21 & 25 & 25 & 22 & 27 & 17 \\
\hline
\end{tabular}

Source: European Union Statistics on Income and Living Conditions 2017-2018. 